\title{
PKM USAHA KERIPIK UBI RUMAH TANGGA DI KECAMATAN MUARA DUA PEMKOT LHOKSEUMAWE
}

\author{
Zaini' ${ }^{1}$, Hanif ${ }^{2}$, Indra Mawardi ${ }^{3}$, Safaruddin 4 \\ 123 Jurusan Teknik Mesin, Politeknik Negeri Lhokseumawe \\ Jl. Banda Aceh-Medan Km. 280,3, Buketrata, Mesjid Punteut, Blang Mangat, Kota \\ Lhokseumawe, Aceh , Indonesia \\ zein_mtm@yahoo.com \\ 4 Jurusan Tata Niaga, Politeknik Negeri Lhokseumawe \\ Jl. Banda Aceh-Medan Km. 280,3, Buketrata, Mesjid Punteut, Blang Mangat, Kota \\ Lhokseumawe, Aceh , Indonesia
}

\begin{abstract}
Abstrak
Tujuan dari kegiatan PKM adalah untuk meningkatkan produksi baik secara kuantitas maupun kualitas usaha keripik di Kecamatan Muara Dua Pemkot Lhokseumawe. Mitra kegiatan PKM usaha keripik ubi ibu Ridna Dewi yang berlokasi di Desa Paloh Batee Kecamatan Muara Dua Pemkot Lhokseumawe. Mitra mempunyai beberapa permasalahan dalam mengembangkan usahanya. Permasalahan utama mitra adalah mitra melakukan proses produksi secara konvensional. Hal ini menyebabkan kapasitas produksi keripik masih rendah dan kualitas keripik masih berminyak sehingga keripik masih kurang renyah dan cepat lembek. Keripik ubi dijual secara curah dengan menggunakan kemasan dari kantong plastik biasa sebagai wadah sehingga produk terlihat masih kurang menarik. Hal ini berpengaruh terhadap daya beli. Didasari permasalahan mitra, maka tim pengabdian menawarkan penyelesaian permasalahan tersebut dengan mekanisasi peraltan kerja dan pelatihan/ pendampingan. Metode penyelesaian permasalahan mitra adalah dengan penerapan teknologi tepat guna. Dimulai dari pembuatan dan implementasi mesin-mesin teknologi tepat guna perajang ubi, mesin peniris minyak, penyediaan kemasan dan peralatan kemasan produk sampai pendampingan. Dari hasil penrapan teknologi tepat guna, usaha keripik ubi ibu Ridna Dewi telah memiliki mesin perajang ubi dan mesin peniris minyak keripik. Mesin yang diberikan telah mampu meningkatkan produksinya mencapai $150 \%$. Mitra telah memiliki peralatan kemasan produk dan plastik keripik untuk meningkatkan pemasaran produk.

Kata Kunci: Keripik Ubi, Produksi, UMKM
\end{abstract}

\section{Pendahuluan}

Lhokseumawe adalah salah satu pemerintahan kota dari 23 kabupaten/kota di provinsi Aceh. Kota Lhokseumawe mempunyai luas wilayah 181,1 km2, dengan 4 (empat) kecamatan yaitu Kecamatan Muara Dua, Kecamatan Muara Satu, Kecamatan Banda Sakti, dan Kecamatan Blang Mangat [1]. Kecamatan Muara Dua mempunyai 17 desa dan merupakan kecamatan yang memiliki wilayah terluas dibandingkan tiga kecamatan lain di kota Lhokseumawe, yaitu sebesar 57,80 km2. Menurut BPS [2], kota Lhokseumawe mempunyai luas dan produksi ubi seluas 24 ha dengan luas panen 23 ha. Kecamatan Muara Dua salah satu kecamatan yang memiliki luas tanaman ubi terluas setelah kecamatan Blang Mangat. 
Ubi merupakan salah satu produk pertanian yang cocok dijadikan unit bisnis, karena manfaat yang diperoleh dari ubi cukup banyak, salah satunya adalah mengolah ubi menjadi keripik. Pangsa pasar keripik masih sangat luas. Usaha keripik ubi saat ini banyak ditekuni oleh masyarakat yang pelakunya adalah industri-industri rumah tangga [3]. Salah satu industri rumah tangga yang mengolah ubi menjadi keripik adalah usaha keripik ubi ibu Ridna Dewi yang berlokasi di Desa Paloh Batee Kecamatan Muara Dua Pemkot Lhokseumawe Provinsi Aceh.

Usaha keripik ubi ibu Ridna Dewi yang menjadi mitra Program Kemitraan Masyarakat (PKM) memulai usahanya pada tahun 2013. Usaha keripik ibu Ridna Dewi berawal dari pesanan teman-teman hingga sekarang menjadi usaha dengan memperkerjakan 4 orang tenaga kerja harian lepas. Dalam proses produksi, Usaha keripik ibu Ridna Dewi mengolah bahan baku ubi kayu (singkong) menjadi keripik sebanyak 50-75 kg/hari. Tinggi rendahnya produksi sangat tergantung dari pesanan. Ubi dibeli dengan harga Rp. 2.000 s.d 2.500 per kg. Usaha keripik ibu Ridna Dewi memproduksi dua jenis keripik yaitu keripik ubi original dengan harga jual Rp. 40.000 per kg dan keripik ubi pedas dengan harga jual Rp. 50.000 per kg.

Usaha keripik ibu Ridna Dewi masih melakukan proses produksi (perajangan dan penirisan minyak) secara konvensional, kualai penggorengan yang kecil. Hal ini menyebabkan kapasitas produksi keripik masih rendah dan kualitas keripik masih 2 berminyak sehingga keripik masih kurang renyah dan cepat lembek. Keripik ubi dijual secara curah dengan menggunakan kemasan dari kantong plastik biasa sebagai wadah sehingga produk terlihat masih kurang menarik. Hal ini berpengaruh terhadap daya beli. Pemasaran keripik juga masih sangat terbatas di wilayah sekitar atau berdasarkan pesanan.

Melalui program pengabdian kepada masyarakat dengan skim PKM, Usaha keripik ibu Ridna Dewi akan diberi sentuhan teknologi berupa penerapan teknologi tepat guna mesin perajang/pengiris ubi, mesin peniris minyak, penyediaan kuali penggorengan besar, penyediaan kemasan dan peralatan kemasan produk sampai pada pelatihan usaha dan pendampingan. Melalui program PKM ini diharapkan Usaha keripik ibu Ridna Dewi akan terjadi peningkatan produksi baik secara kuantitas maupun kualitas sehingga usaha rumah tangga ini akan mandiri secara ekonomi dan sosial.

Beberapa program yang serupa telah dilakukan dengan tingkat keberhasilan yang cukup baik, antara lain; Gatot [4] telah melakukan Iptek Bagi Masyarakat: kelompok usaha kripik singkong di kelurahan pagentan kecamatan Singosari kabupaten Malang. Pengabdian difokuskan pada penyediaan mesin perajang dan kompor penggorengan berbahan bakar gas. Hasil pengabdian menunjukan Kesejahteraan pemilik usaha (mitra) dan karyawan meningkat mencapai $100 \%$. Suriadi [5] telah melakukan penerapan mesin pengiris singkong pada industri kecil Jurnal Pengabdian Kepada Masyarakat MEDITEG Volume 4, Nomor 1, September 2019 Copyright $\odot 2019$ Jurnal Pengabdian Kepada Masyarakat MEDITEG 
kripik singkong. Kelompok usaha pembuatan kripik singkong Niki Suka dan UD. Gurih Sari terdapat di kabupaten Negara menjadi mitra. Produksi kripik masih memanfaatkan sumber daya lokal dengan cara yang masih konvensional. Hasil pengabdian menunjukan tim telah berhasil merancang mesin/alat pengiris singkong yang dapat membantu pengusaha kecil kripik singkong dalam meningkatkan hasil produksi. Dimana dari hasil analisa tersebut terdapat peningkatan produksi mencapai 10 kali lipat. Kegiatan pengabdian kepada masyarakat di Kabupaten Aceh Besar telah dilakukan. Kegiatan pengabdian tersebut berupa peningkatan kualitas keripik ubi melalui penerapan mesin peniris dan kemasan produk pada usaha keripik ubi di Saree Kabupaten Aceh Besar [6].

Pemanfaatan kulit singkong sebagai keripik telah dilakukan di Kelurahan Cinere pemerintahan Kota Depok. Bagian dari kulit singkong yang dianggap limbah juga masih memiliki kandungan karbohidrat yang dapat dimanfaatkan. Pengolahan kulit singkong menjadi keripik dapat dijadikan solusi untuk mengatasi limbah kulit singkong sekaligus memberikan peluang usaha bagi ibu-ibu rumah tangga. [7]. Kegiatan Ipteks bagi masyarakat (IbM) pada UKM Kripik Tempe Elang Jawa dan UKM Kripik Tempe Selera Pemberani tepatnya di wilayah jalan Sanan Kelurahan Purwantoro Kecamatan Blimbing Kota Malang telah dilakukan. Hasil kegiatan menunjukan penghasilan semakin meningkat $10 \%$ dari kedua mitra, kapasitas semakin bertambah 20\% sehingga dapat memenuhi permin-taan pasar, beban pekerjaan semakin ringan sehingga tidak diperlukan tenaga kerja tambahan, dan waktu proses lebih efektif 1,5-2 jam [8]. I Made Kastiawan [9] telah melaksanakan pengabdian untuk kelompok usaha rumah tangga aneka keripik dan sale pisang Desa Wonodadi Kulon. Pada kegiatan ini juga dilakukan penerapan teknologi tepat guna

Sucihatiningsih [10] telah melakukan pengabdian untuk petani sayur pengolahan kripik terong dan wortel di desa lanjan kecamatan Sumowono Kabupaten Semarang. Setelah pengabdian ini dilaksanakan, mitra mampu memecahkan permasalahan yang ada sehingga dapat menunjang peningkatan ekonomi masyarakat petani sayur dan daerah setempat. Pengabdian pembuatan keripik gandum telah dilakukan. Keripik gadung adalah makanan spesial terbuat dari umbi gadung yang melalui proses produksi yang panjang dan rumit, kemudian dijemur sampai kering dan selanjutnya digoreng dan dikemas. Desa Gogik merupakan salah satu desa di kecamatan Ungaran Barat, berada dilereng gunung ungaran sebelah timur dengan potensi tanaman umbi gadung cukup besar. Hasil yang diperoleh adalah: desain dan pembuatan mesin perajang \& oven pengering, dan mesin kemasan manual (hand sealer). [11].

\section{Metode Pelaksanaan}


Dalam penyelesaian permasalahan mitra, metode yang diterapkan adalah dengan menerapkan teknologi tepat guna. Teknologi tepat guna yang perlu diimplemtasikan adalah mesin perajang dan mesin peniris minyak. Kedua teknologi ini akan dapat meningkatkan produksi, baik kuantitas maupun kualitas produk. Metode pelaksanaan pengabdian kepada masyarakat dilakukan dalam beberapa tahap.

\section{Pembuatan mesin perajang ubi}

Mesin perajang ubi digunakan untuk mengiris ubi agar ketebalan ubi yang diiris bisa rata ketebalannya, dan kapasitas iris lebih banyak. Mesin peniris ubi yang akan difabrikasi mempunyai mempunyai spesifikasi; kapasitas $50-100$ kg/jam, mata perajang berbentuk piringan dengan 3 pisau perajang, dan putaran 300 rpm. Sumber tenaga penggeraknya adalah motor listrik. Skema desain mesin perajang ubi yang akan difabrikasi nantinya diperlihatkan pada Gambar 1.

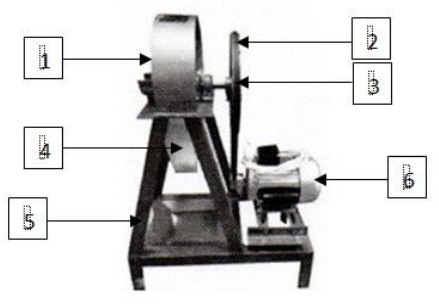

Keterangan gambar:

1. Mata pengiris

2. Puli dan sabuk

3. Poros

4. Rangka

5. Rangka

6. Motor

Gambar 1. Skema desain mesin perajang ubi

\section{Pembuatan mesin peniris minyak}

Mesin peniris minyak berfungsi mengurangi kadar minyak dalam produk keripik ubi nantinya. Mesin peniris minyak yang dibuat nantinya merupakan model mesin teknologi tepat guna yang mudah dalam pengoperasian dan perawatan. Mesin peniris minyak yang akan difabrikasi mempunyai kapasitas 50-100 kg/jam. Mesin ini dirancang agar mampu meniriskan minyak pada keripik ubi dengan waktu yang lebih cepat. Mesin ini mempunyai 2 buah tabung yang dipasang seporos, yaitu tabung peniris dan tabung penampung. Mesin ini juga mempunyai sistem transmisi tunggal berupa sepasang puli yang dihubungkan dengan sebuah sabuk V. Mesin peniris menggunakan motor listrik sebagai penggerak. Gambar 2 memperlihatkan mesin peniris minyak untuk keripik yang akan dibuat. Mesin perajang ubi dan peniris minyak akan dimanufaktur di Laboratorium Teknologi Mekanik Jurusan Teknik Mesin Politeknik Negeri Lhokseumawe.

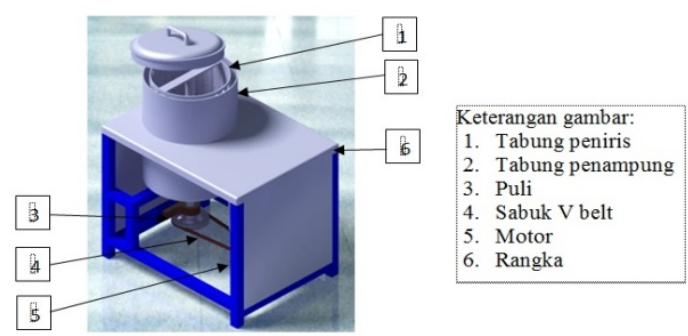

Gambar 2. Sketsa desain mesin peniris minyak yang difabrikasi

\section{Implementasi kegiatan}

Implementasi kegiatan dilakukan dengan penyediaan mesin mesin perajang ubi dan peniris minyak, penyediaan kulai penggorengan yang besar dan penyediaan kemasan serta peralatan kemasan produk. Mesin yang telah dimanufaktur akan diberikan kepada mitra. Mitra akan dilatih cara penggunaan dan perawatan mesin 
peniris minyak. Dengan tersedianya mesin perajang dan peniris minyak secara tidak langsung akan meningkatkan kuantitas ubi rajangan dan kualitas keripik ubi nantinya. Proses penggorengan keripik dengan kuali berukuran kecil membutuhkan waktu yang lama. Oleh karena itu, untuk meningkatkan produktifitas perlu juga didukung dengan ketersediaan kuali penggorengan yang lebih besar. Pada kegiatan nantinya akan disediakan kuali yang lebih besar untuk pengorengan keripik. Keripik ubi yang dihasilkan mitra selama ini belum menggunakan kemasan yang representatif. Hal ini berefek produk keripik cepat lembek dan sulit memasuki pasar swalayan atau supermarket. Model kemasan nantinya akan dirancang dalam bentuk kotak atau plastik yang bergambar. Kemasan plastik menggunakan alat hand seller sehingga kemasan tidak mudah bocor.

\section{Evaluasi pelaksanaan}

Evaluasi dilakukan untuk melihat tingkat keberhasilan dan keberlanjutan program setelah masa kegiatan PKM berakhir. Evaluasi akan dilakukan secara berkala setiap bulan selama tahun setelah kegiatan selesai.

\section{Hasil Kegiatan}

\section{Penerapan Teknologi Tepat Guna}

Penerapan teknologi tepat guna merupakan salah satu bentuk penyelesaian permasalahan Mitra. Mesin perajang ubi digunakan untuk mengiris ubi agar ketebalan ubi yang diiris bisa rata ketebalannya, dan kapasitas iris lebih banyak. Mesin peniris ubi yang akan difabrikasi mempunyai mempunyai spesifikasi; kapasitas 100-150 kg/jam, mata perajang berbentuk piringan dengan 3 pisau perajang, putaran $300 \mathrm{rpm}$ dan konsumsi listrik sekitar 200 watt. Mesin ini sangat cocok untuk usaha keripik ubi dalam upaya meningkatkan kuantitas ubi untuk keripik. Mesin ini juga mempunyai sistem transmisi tunggal berupa sepasang puli yang dihubungkan dengan sebuah sabuk $\mathrm{V}$. Sumber tenaga penggeraknya adalah motor listrik.

Mesin peniris minyak yang akan difabrikasi mempunyai kapasitas 50-100 $\mathrm{kg} / \mathrm{jam}$. Mesin ini sangat cocok untuk usaha keripik ubi dalam upaya meningkatkan kualitas keripik ubi. Mesin ini dirancang dan difabrikasi untuk mengurangi kadar minyak pada keripik ubi dengan waktu yang lebih cepat, yang semula membutuhkan waktu yang lama. Mesin peniris minyak yang dibangun mempunyai 2 buah tabung yang dipasang seporos, yaitu tabung peniris dan tabung penampung. Mesin ini juga mempunyai sistem transmisi tunggal berupa sepasang puli yang dihubungkan dengan sebuah sabuk V. Sumber tenaga penggeraknya adalah motor listrik. Mesin dirancang dan difabrikasi sedemikian rupa sehingga mudah dalam pengoperasian dan perawatan. Gambar 3 memperlihat mesin perajang ubi dan mesin peniris minyak yang telah dibuat unt diterapkan kepada mitra. 


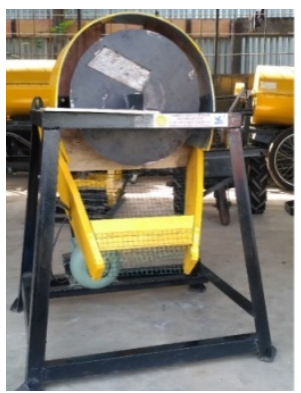

(a)

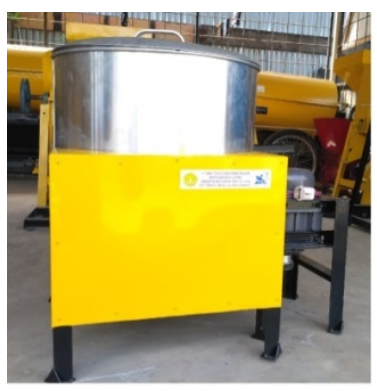

(b)
Gambar 3. Mesin teknologi tepat guna yang telah difabrikasi (a) perajang ubi dan (b) mesin peniris minyak

\section{Implementai Kegiatan}

Pelaksanaan kegiatan PKM usaha keripik ubi ibu Ridna Dewi yang berlokasi di Desa Paloh Batee Kecamatan Muara Dua Pemkot Lhokseumawe Provinsi Aceh telah dilakukan. Pada kegiatan implementasi ini selain memberikan mesin TTG, mitra diberi teknik pengoperasian dan melakukan perawatan mesin dengan baik. Tim PKM telah melakukan arahan serta contoh, dan dipraktekan langsung oleh mitra bagaimana cara mengoperasikan mesin.

Teknik perajangan, mulai pengaturan ketebalan keripik sampai mengatur bentuk keripik telah diberikan petunjuk dan contoh praktek dilapangan. Hasil rajangan terhadap ubi yang dihasilkan menjadi seragam. Pelatihan penggunaan mesin perajang juga memberikan teknik perawatan mesin, keselamatan kerja dan cara-cara mengatasi kerusakan yang akan terjadi. Dari hasil implementasi mesin perajang ubi, mitra telah dapat menggunakan mesin perajang dengan baik.

Hal yang sama juga dilakukan pada implementasi mesin peniris minyak. Mesin peniris minyak sistem sentrifugal yang digunakan dapat mempercepat proses penirisan minyak sehingga keripik menjadi lebih kering dan renyah. Proses penirisan sangat cepat berkisar 1 sampai 3 menit untuk sekali penirisan. Gambar 4 memperlihatkan beberapa kegiatan implementasi penerapan mesin perajang dan peniris keripik.

Dengan kapasitas mesin perajang ubi dan peniris minyak yang diberikan ke mitra, masing-masing 50-100 $\mathrm{kg} / \mathrm{jam}$, telah meningkatkan produksi mitra. Penerapan mekanisasi peralatan kerja pada usaha keripik telah mampu meningkatkan produksi keripik mencapai 150\% dibandingkan sebelum penerapan mekanisasi peralatan kerja.

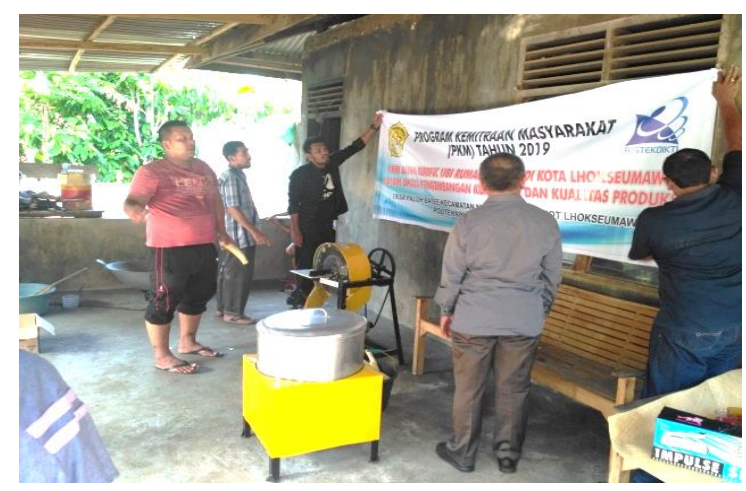

Gambar 4. Penyerahan mesin teknologi tepat guna

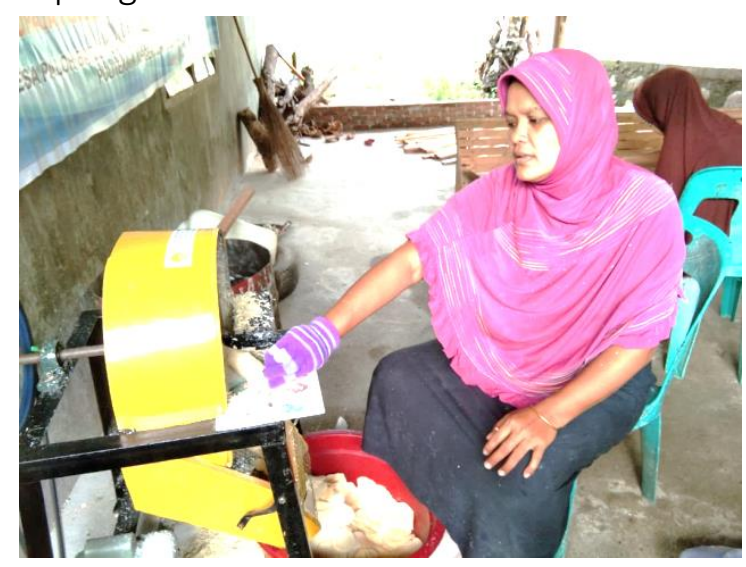

Jurnal Pengabdian Kepada Masyarakat MEDITEG

Volume 4, Nomor 1, September 2019

Copyright @ 2019 Jurnal Pengabdian Kepada Masyarakat MEDITEG 
Gambar 5. Implementasi teknologi tepat guna

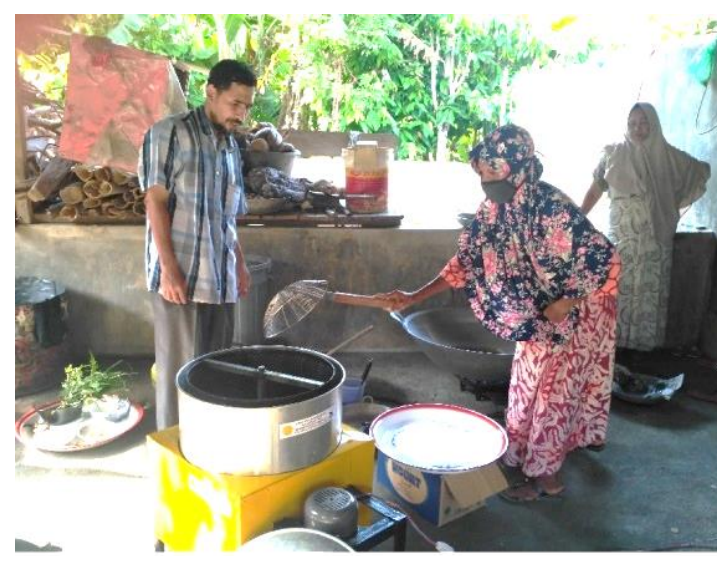

Gambar 6. Implementasi teknologi tepat guna

Kemasan sekarang tidak hanya merupakan suatu konsep fungsional sebatas untuk melindungi barang atau mempermudah barang untuk dibawa, tetapi telah menjadi bagian penting yang harus mencakup seluruh proses pemasaran dari konsepsi produk sampai ke pemakai terakhir. Keripik ubi yang dihasilkan mitra selama ini belum menggunakan kemasan yang representatif. Hal ini berefek produk keripik cepat lembek dan kurang menarik sehingga sulit memasuki pasar swalayan atau supermarket.

Pada kegiatan PKM ini, tim membekali mitra dengan model kemasan dari plastik yang transparan dapat mempunyai label produksi. Dengan adanya bentuk kemasan yang diimplementasikan, bentuk produk kelihatan lebih menarik. Melalui ketersediaan kemasan produk ini diharapkan penjualan keripik dapat meningkat. Gambar 5 memperlihatkan mitra melakukan proses pengemasan dan produk yang telah siap jual.

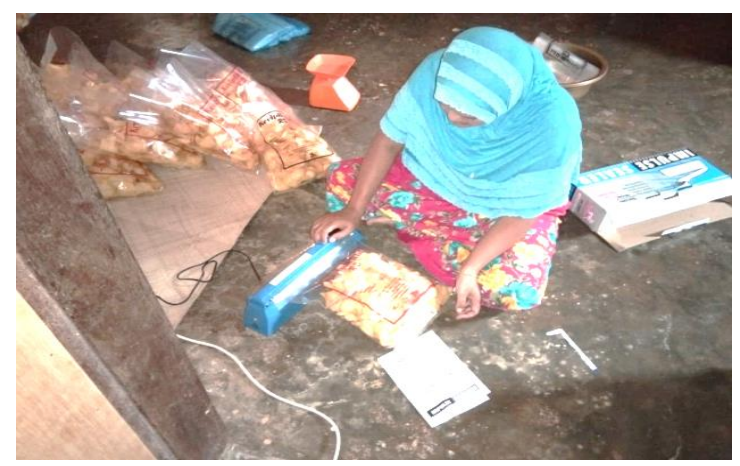

(a)

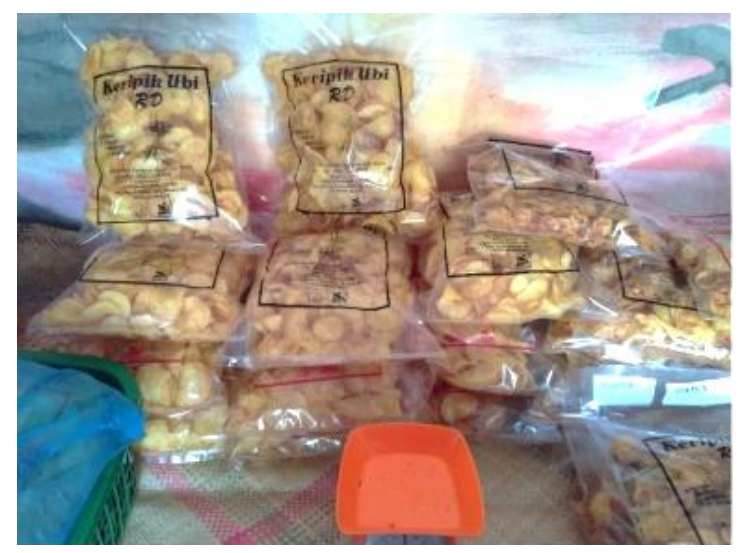

(b)

Gambar 5. (a) Proses pengemasan dan (b) Produk setelah kegiatan

\section{KesIMPULAN}

Telah dilakukan penerapan teknologi tepat guna berupa mesin perajang ubi dan mesin peniris minyak keripik pada usaha keripik ubi ibu Ridna Dewi yang berlokasi di Desa Paloh Batee Kecamatan Muara Dua Pemkot Lhokseumawe Provinsi Aceh. Mesin yang diberikan telah mampu meningkatkan produksinya menjadi 50-100 $\mathrm{Kg} / \mathrm{jam}$ dalam bentuk irisan yang siap digoreng. Sehingga dengan demikian juga 
akan memberikan dampak pada produksi siap jual (sudah digoreng) yang meningkat 150\%. Mitra telah memiliki peralatan kemasan produk dan plastik keripik untuk meningkatkan pemasaran produk.

\section{UCAPAN TERIMA KASIH}

Ucapan terimakasih disampaikan kepada Kemenristek-dikti atas bantuan dana yang diberikan melalui Program Kemitraan Masyarakat (PKM) Tahun Anggaran 2019.

\section{Daftar PUstaka}

D. W. P. Sucihatiningsih, A. Kuswardinah, And F. Fafurida, "Ibm Untuk Petani Sayur Pengolahan Kripik Terong dan Wortel Di Desa Lanjan Kecamatan Sumowono Kabupaten Semarang," Rekayasa, Vol. 13, No. 2, 2015.

D. Chrismianto, K. Kiryanto, And I. Sumantri, "Ibm Kelompok Usaha Keripik Gadung Melalui Peningkatan Kualitas Produk Dan Manajemen Pemasaran di Ungaran Barat Kabupaten Semarang," Abdimas Unwahas, Vol. 3, No. 1, 2018.

E. D. . Yuni Retnaningtyas, Ibm Pengusaha Keripik Singkong Rumah Tangga, Laporan IbM, Universitas Jember, 2015.

F. Suryanti And K. A. Mediaswati, "Usaha Kecil dan Menengah Keripik Tempe di Kecamatan Blimbing Kota Malang Untuk Peningkatkan Pendapatan Usaha," Jast J. Apl. Sains Dan Teknol., Vol. 1, No. 1, 2017.
G. Soebiyakto And A. Alfiana, Iptek Bagi Masyarakat: Kelompok Usaha Kripik Singkong di Kelurahan Pagentan Kecamatan Singosari Kabupaten Malang, Jati Emas (Jurnal Apl. Tek. Dan Pengabdi. Masyarakat), Vol. 1, No. 1, Pp. 1-4, 2017.

Hanif, Indra Mawardi, Safaruddin, "Peningkatan Kualitas Keripik Ubi Melalui Penerapan Mesin Peniris Dan Kemasan Produk Pada Usaha Keripik Ubi Saree di Kabupaten Aceh Besar," In Prosiding Sendimas 2017, 2017, Vol. 2, No. 1, Pp. 34-39.

I. G. A. K. Suriadi, I. D. G. A. Subagia, And I. K. A. Atmika, Penerapan Mesin Pengiris Singkong Pada Industri Kecil Kripik Singkong," Bul. Udayana Mengabdi, Vol. 15, No. 2, Pp. 118-124.

L. Aryani And D. Triwardhani, "Ibm Pada Kelompok Ibu-lbu Mengolah Kulit Singkong di Desa Cinere Kota Depok," Pros. Snapp Sos. Ekon. Dan Hum., Vol. 7, No. 2, Pp. 337-343, 2017.

I. M. Kastiawan And A. Maqsudi, "Ibm Kelompok Usaha Rumah Tangga Aneka Keripik dan Sale Pisang Desa Wonodadi Kulon," Jpm17 J. Pengabdi. Masy., Vol. 1, No. 01, 2014.

Http://www.Lhokseumawe.go.Id," 2018.

[Accessed: 19-Aug-2018]

Http://Aceh.BPS.go.Id,"/Statictable/2015/

08/21/33/Luas-Dan-Produksi-

Tanaman-Ubi-Jalar-Menurut-

Kabupaten-Kota-2013, 2013. [Online]. [Accessed: 19-Aug-2018] 